\title{
Combined Testing of p16 Tumour-suppressor Protein and Human Papillomavirus in Patients With Oral Leukoplakia and Oral Squamous Cell Carcinoma
}

\author{
JONAS SUNDBERG ${ }^{1}$, MAGDALENA KORYTOWSKA ${ }^{2}$, PATRICIA MIRANDA BURGOS ${ }^{2}$, \\ JOHAN BLOMGREN ${ }^{3}$, LENA BLOMSTRAND ${ }^{4}$, SHAHIN DE LARA ${ }^{5}$, LARS SAND ${ }^{6}$, \\ JAN-MICHÁEL HIRSCH ${ }^{4}$, ERIK HOLMBERG ${ }^{7}$, DANIEL GIGLIO ${ }^{7}$, JENNY ÖHMAN ${ }^{1}$, \\ ANIKÓ KOVÁCS ${ }^{5}$, PETER HORAL ${ }^{8}$, MAGNUS LINDH $^{8}$, GÖRAN KJELLER ${ }^{9}$ and BENGT HASSÉUS ${ }^{1}$ \\ ${ }^{1}$ Department of Oral Medicine and Pathology, Institute of Odontology, \\ Sahlgrenska Academy, University of Gothenburg, Gothenburg, Sweden; \\ ${ }^{2}$ Clinic of Orofacial Medicine and Maxillofacial Surgery, NÄL Hospital, Trollhättan, Sweden; \\ ${ }^{3}$ Clinic of Orofacial Medicine, Sahlgrenska University Hospital/East, Gothenburg, Sweden; \\ ${ }^{4}$ Plastic \& Oral and Maxillofacial Surgery, Department of Surgical Sciences, Uppsala University, Uppsala, Sweden; \\ ${ }^{5}$ Department of Clinical Pathology, Sahlgrenska University Hospital, Gothenburg, Sweden; \\ ${ }^{6}$ Department of Oral Biology, Faculty of Odontology, University of Oslo, Oslo, Norway; \\ ${ }^{7}$ Department of Oncology, Institute of Clinical Sciences, \\ Sahlgrenska Academy, University of Gothenburg, Gothenburg, Sweden; \\ ${ }^{8}$ Department of Infectious Medicine, Institute of Biomedicine, \\ Sahlgrenska Academy, University of Gothenburg, Gothenburg, Sweden; \\ ${ }^{9}$ Department of Oral and Maxillofacial Surgery, Sahlgrenska Academy, \\ University of Gothenburg, Gothenburg, Sweden
}

\begin{abstract}
Background: Oral leukoplakia $(O L)$ is a potentially malignant oral mucosal disorder. A casual association between OL, oral squamous cell carcinoma (OSCC) and human papillomavirus (HPV) infection has been suggested, but no conclusive evidence has been presented. p16, a tumoursuppressor protein, is used as a surrogate marker for HPV infection. The aim of this study was to investigate how overexpression of p16 correlates with HPV infection in OL and in OSCC. Patients and Methods: Seventy-four patients with $O L$ and 13 with OSCC with p16 overexpressed, were analyzed by immunohistochemistry visualizing p16 and a real-time polymerase chain reaction (PCR) assay targeting HPV types $6,11,16,18,31,33,35,39,45,52,56,58$ and 59. Results: Overexpression of pl6 was observed in $18 \%$ of patients with
\end{abstract}

This article is freely accessible online.

Correspondence to: Bengt Hasséus, LDS, Ph.D., Department of Oral Medicine and Pathology, Institute of Odontology, Sahlgrenska Academy, University of Gothenburg, PO Box 450, SE40530 Gothenburg, Sweden. Tel: +46 317863842, e-mail: Bengt.Hasseus@gu.se

Key Words: Potentially malignant oral disorders, oral cancer, tumour suppressor protein, virus infection, biomarker.
OL. None of the HPV subtypes were detected by PCR analysis in patients with OL. In the p16-positive OSCC specimens, $38 \%$ were also HPV16-positive. Conclusion: Overexpression of p16 was not found to be a reliable biomarker for HPV infection in patients with $O L$ and OSCC.

Oral squamous cell carcinoma (OSCC) is the result of a multi-step process during which genetic alterations transform normal cells into cancer cells (1). The appearance of tumours is often preceded by a potentially malignant oral disorder (2, 3 ). Oral leukoplakia (OL) is one of the most prevalent potentially malignant oral disorders, with the potential to turn into OSCC. Depending on the clinical presentation, leukoplakia can be divided into homogeneous and nonhomogeneous forms (Figure 1), where the latter has been attributed a higher risk of malignant transformation (4).

Warnakulasuriya and Ariyawardana reported an estimated overall malignant transformation rate for OL of $3.5 \%$, with a wide range from $0.13 \%$ to $34.0 \%$ (4). The annual transformation rate for OL is estimated to be in the range of 1.0$2.6 \%(5,6)$. Suggested treatment protocols for OL are surgical excision and surveillance (7-10). Even after radical surgical removal, OL recurrence rates are reported to be in the range of $10-20 \%$ and despite surgical intervention, cancer transformation occurs in $3-9 \%$ of cases at the site of the excised lesion $(7,9)$. 
Many signalling pathways and genes have been implicated in both cell dysplasia and malignant transformation in OL. Genetic alterations, including changes in genes that regulate genomic stability, the cell cycle, the cytoskeleton, angiogenesis, and apoptosis, have been suggested to be drivers of tumourigenesis in cases of OL (11-13).

The exogenous factors that cause DNA damage include viral infection, which can promote progression to malignancy by different mechanisms. The capacity of human papillomavirus (HPV), especially of HPV type 16, to become incorporated into the host DNA of infected epithelial cells is believed to increase the risk of cancer development (14-16). The associations of cancer of the cervix uteri and squamous cell carcinoma in the oropharynx with high-risk HPV (HRHPV) infection are well known (17-20). Over the past two decades, the incidence of oropharyngeal squamous cell carcinoma (OPSCC) related to HPV infection has increased alarmingly (21-23). In the oral cavity, a casual association between HPV and OL, as well as between HPV and OSCC, has been suggested by several groups, although no conclusive evidence for such an association has been presented (24-32).

The tumour-suppressor protein p16 (also known as p $16^{\text {INK4a }}$, cyclin-dependent kinase inhibitor 2A) inhibits the binding of the cyclin-dependent kinases 4 and 6 to cyclin D1. This inhibits the phosphorylation of retinoblastoma protein $(\mathrm{RB})$, which is needed for release of the E2F transcription factor to enable E2F to enter the cell cycle (33, 34). This pathway can be disturbed by a HR-HPV infection by the viral oncoprotein E7. E7 binds to and inactivates pRB, allowing E2F to induce cell-cycle progression and to promote the transcription of the $p 16$ gene. Thus, p16 can serve as a surrogate marker for HR-HPV infection $(33,35)$.

In OPSCC, the overexpression of p16 in tumour tissue is a well-established surrogate marker for HR-HPV infection, and is used both in clinical and scientific protocols $(36,37)$. The expression patterns of p16 in OL and OSCC have been investigated in several studies. No conclusive evidence of a correlation between p16 expression, HPV infection and malignant transformation has been presented. Some studies have also suggested that p16 expression differs between anatomical sites in the oral cavity (38-41).

Thus, based on current knowledge, the correlation between p16 and HPV infection in OL and OSCC is uncertain. The aim of this study was to explore the correlation between the overexpression of p16 and HPV infection in both OL and OSCC.

\section{Patients and Methods}

Patients. Ninety-five patients who participated in a prospective longitudinal multi-centre study in Sweden (ORA-LEU-CAN Study) between 2011 and 2017, were included. The inclusion criterion was a clinically and histopathologically verified diagnosis of OL. Data
Table I. Clinical characteristics of the patients with oral leukoplakia $(N=81)$.

\begin{tabular}{|c|c|}
\hline Characteristic & $\mathrm{N}(\%)$ \\
\hline \multicolumn{2}{|l|}{ Gender } \\
\hline Male & $39(48)$ \\
\hline Female & $42(52)$ \\
\hline \multicolumn{2}{|l|}{ Age (at first appointment), years } \\
\hline$<50.0$ & $11(13)$ \\
\hline $50.0-59$ & $25(31)$ \\
\hline$\geq 60.0$ & $45(56)$ \\
\hline \multicolumn{2}{|l|}{ Site of lesion } \\
\hline Floor of the mouth & $5(6)$ \\
\hline Buccal mucosa & $17(21)$ \\
\hline Lateral tongue & $19(24)$ \\
\hline Ventral tongue & $5(6)$ \\
\hline Dorsal tongue & $1(1)$ \\
\hline Soft palate & $1(1)$ \\
\hline Hard palate & $3(4)$ \\
\hline Alveolar gingiva & $27(33)$ \\
\hline Lip & $3(4)$ \\
\hline \multicolumn{2}{|l|}{ Clinical diagnosis } \\
\hline Homogenous leukoplakia & $54(67)$ \\
\hline Non-homogenous leukoplakia & $27(33)$ \\
\hline \multicolumn{2}{|l|}{ Histopathological diagnosis } \\
\hline Benign hyperkeratosis & $63(78)$ \\
\hline Lichenoid reaction & $1(1)$ \\
\hline Mild dysplasia & $13(16)$ \\
\hline Moderate dysplasia & $3(4)$ \\
\hline Severe dysplasia & $1(1)$ \\
\hline \multicolumn{2}{|l|}{ Smoker } \\
\hline Yes & $25(31)$ \\
\hline No & $55(68)$ \\
\hline No data & $1(1)$ \\
\hline \multicolumn{2}{|l|}{ Previous smoker } \\
\hline Yes & $45(56)$ \\
\hline No & $30(37)$ \\
\hline No data & $6(7)$ \\
\hline \multicolumn{2}{|l|}{ Use of snuff } \\
\hline Yes & $7(6)$ \\
\hline No & $73(89)$ \\
\hline No data & $1(5)$ \\
\hline \multicolumn{2}{|l|}{ Previous use of snuff } \\
\hline Yes & $14(17)$ \\
\hline No & $57(70)$ \\
\hline No data & $10(13)$ \\
\hline \multicolumn{2}{|l|}{ Alcohol consumption } \\
\hline Daily & $0(0)$ \\
\hline Several times per week & $12(15)$ \\
\hline Once a week & $29(36)$ \\
\hline Never/rarely & $34(42)$ \\
\hline No data & $6(7)$ \\
\hline
\end{tabular}

on medical and dental histories, tobacco habits, clinical appearance (homogenous and non-homogenous) OL, and localisation and size of the lesion, together with clinical photographs and the results of biopsy analysis were collected. Histopathological diagnoses were established by Board-certified specialists both in general pathology and subspecialized in oral pathology. 

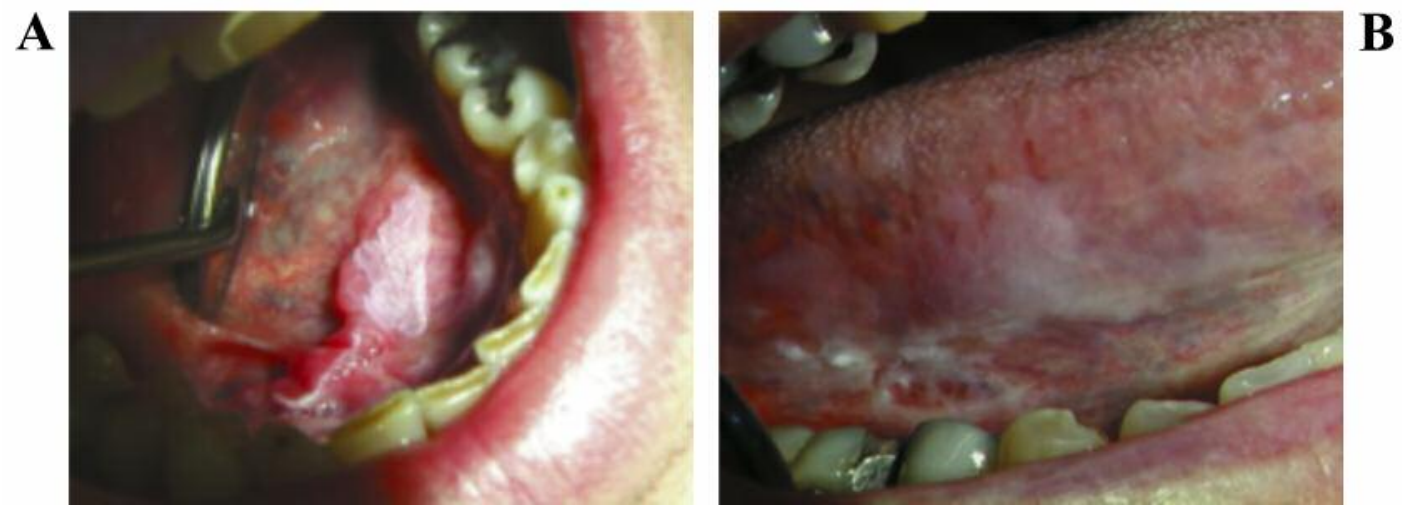

Figure 1. Clinical presentation of homogenous leukoplakia in the floor of the mouth (A) and non-homogenous leukoplakia at the lateral border of the tongue $(B)$.
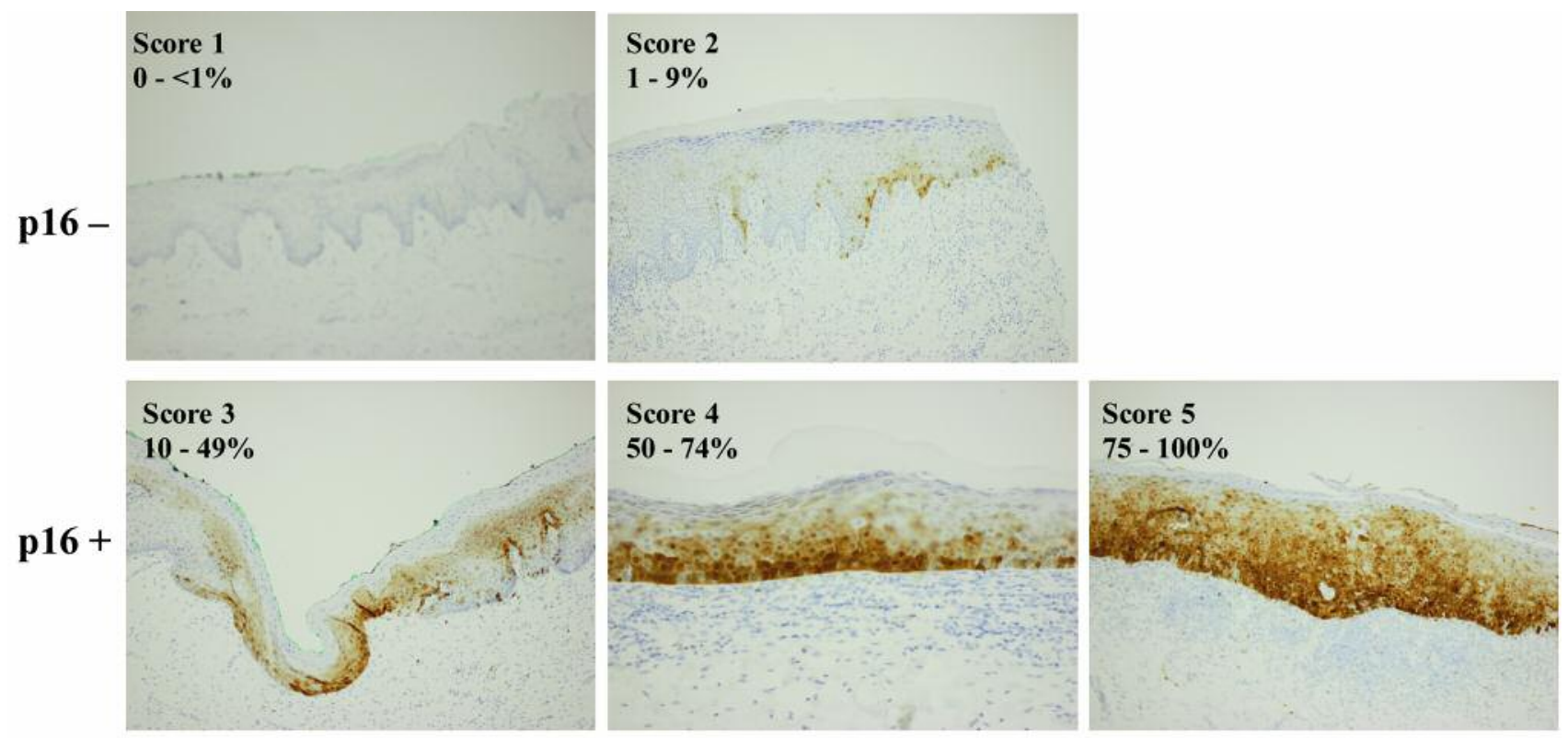

Figure 2. Semi-quantitative assessment of p16 expression based on the percentage of p16 expression detected in the epithelial layer. Samples with scores in the range of 3-5 were regarded as p16-positive. The magnification in pictures 1,2, 3 and 5 is $\times 100$ and in picture 4 it is $\times 200$.

The clinical diagnosis was re-reviewed by two specialists in oral medicine. If there was a discordant opinion regarding a diagnosis, a discussion was initiated until consensus was reached. Of the 95 recruited patients, 14 were excluded: 10 because the diagnosis was revised and four because the diagnosis was uncertain. Thus, 81 patients were included in the final analysis.

For comparison, 15 patients with a clinical and histopathological diagnosis of OSCC and five patients with cervical carcinomas were included, because previous examinations had classified them as p16positive. Paraffin-embedded samples from these cases were retrieved from the Diagnostic Biobank at the Department of Clinical Pathology, Sahlgrenska University Hospital, Gothenburg, Sweden. Re-evaluation of p16 positivity was carried out by a senior pathologist (AK). Two patients with OSCC that were previously considered to be p16-positive were by re-assessment classified as p16-negative and therefore excluded. The five patients with cervical carcinoma were confirmed to be p16-positive. This latter group of patients formed the positive control group for the polymerase chain reaction (PCR) analysis. The characteristics of the patients with OL are listed in Table I and those of the patients with OSCC are listed in Table II.

Immunohistochemistry. Sections from paraffin-embedded biopsies were prepared, and immunohistochemistry was performed. Formalin-fixed and paraffin-embedded (FFPE) blocks were used to prepare $4-\mu \mathrm{m}$-thick sections that were placed onto positively charged slides (Flex IHC Microscope Slides; DAKO, Glostrup, Denmark). Subsequently, the tissue sections were subjected to 
deparaffinisation and rehydration followed by heat-induced epitope retrieval in Tris/EDTA buffer ( $\mathrm{pH} \mathrm{9.0)} \mathrm{for} 20 \mathrm{~min}$ at $97^{\circ} \mathrm{C}$ using a PT Link instrument (DakoCytomation, DAKO).

The tissue sections were immunostained with mouse monoclonal antibody to p16 (clone E6H4, CINtec Histology Kit; Roche Diagnostics $\mathrm{GmbH}$, Mannheim, Germany;) using the DAKO visualisation system [EnVision FLEX, High pH (Link); DAKO] and DAKO Autostainer Plus for IHC (DakoCytomation, DAKO) following the manufacturer's instructions. Peroxidase-catalysed diaminobenzidine tetrahydrochloride was used as the chromogen to determine the protein expression levels in tumours from head and neck cancer of unknown primary, and then the slides were counterstained with haematoxylin (EnVision FLEX Hematoxylin; DAKO). The stained slides were rinsed with deionised water followed by a dehydration series in $70 \%$ ethanol, $95 \%$ ethanol, and absolute ethanol, and then cleared in xylene and a cover-glass (Coverslipper; DAKO) added. Sections from tonsillar cancer tissues served as positive controls, while omission of the primary antibodies served as negative controls.

Semi-quantitative analysis of p16 expression. Expression of p16 was recorded and evaluated using a semi-quantitative scale based on the percentage of p16 expression detected in the epithelial layer, using the following scoring scheme: $1: 0-1 \% ; 2: 1-9 \% ; 3: 10-49 \% ; 4: 50-$ 74\%; and 5: 75-100\% (Figure 2). Samples with scores in the range of 3-5 were regarded as p16-positive.

HPV DNA analysis. Formalin-fixed, paraffin-embedded tissue samples were sectioned $(30 \times 5 \mu \mathrm{m})$ using a microtome, with precautions taken to ensure that there was no contamination between cases. After each set of sections, the microtome was cleaned with Invitrogen DNAZap, (Thermo Fisher Scientific, Waltham, MA, USA), to avoid cross-contamination between the samples.

Xylene was used for deparaffinisation. The DNA extractions were performed using QIAamp DNA FFPE Tissue kit (Qiagen, Hilden, Germany), according to the manufacturer's protocol. The concentration and purity of the extracted DNA were analysed in a spectrophotometer.

A TaqMan real-time PCR assay targeting 12 HR-HPV types (16, $18,31,33,35,39,45,51,52,56,58$ and 59) and two low-risk HPV (LR-HPV) types (6 and 11), including the primers and probes presented in Table III, was used for identification of HPV DNA (42). As quality control, real-time PCR for the human betaglobin gene was run in parallel, and only samples with a betaglobin Ctvalue of below 40 were included in the study. Seven patients from the OL group were accordingly excluded, resulting in 74 patients remaining in the OL group.

The Ethical Review Board in Gothenburg approved the study (Dnr. 673-10/T872-18).

Statistical analysis. Statistical analyses were carried out using the Prism 8 software (GraphPad Software Inc., San Diego, CA, USA). Analyses of differences between groups were performed using Fisher's exact test. A $p$-value of less than 0.05 was considered statistically significant.

\section{Results}

p16 expression and PCR analysis of samples of OL. Among the 74 patients in the OL group, p16 overexpression was observed in 13 patients (18\%). None of the 74 patients with
Table II. Patterns of p16 expression in the patients with oral leukoplakia $(O L)$ and patients with oral squamous cell carcinoma (OSCC) according to characteristics of the cancer in these patients.

\begin{tabular}{lccc}
\hline & \multicolumn{2}{c}{ OL, N (\%) } & OSCC, N (\%) \\
\cline { 2 - 3 } & $\begin{array}{c}\text { p16-Positive } \\
\text { Patients }\end{array}$ & $\begin{array}{c}\text { p16-Negative } \\
(\mathrm{N}=13)\end{array}$ & $\begin{array}{c}\text { p16-Positive } \\
(\mathrm{N}=13)\end{array}$ \\
\hline Gender & & & \\
Male & $7(54 \%)$ & $29(48 \%)$ & $9(69 \%)$ \\
Female & $6(46 \%)$ & $32(52 \%)$ & $4(31 \%)$ \\
Cancer transformation & $0(0 \%)$ & $4(7 \%)$ & - \\
HPV PCR result & & & \\
Positive & $0(0 \%)$ & $0(0 \%)$ & $5(38 \%)$ \\
Negative & $13(100 \%)$ & $61(100 \%)$ & $8(62 \%)$ \\
Clinical diagnosis & & & \\
Homogenous & $10(77 \%)$ & $42(69 \%)$ & - \\
Non-homogenous & $3(23 \%)$ & $19(31 \%)$ & - \\
Dysplasia & & & \\
Yes & $4(31 \%)$ & $10(16 \%)$ & - \\
$\quad$ No & $9(69 \%)$ & $51(84 \%)$ & - \\
Site of lesion & & & \\
Tongue & $2(15 \%)$ & $19(31 \%)$ & $2(15 \%)$ \\
Buccal mucosa & $3(23 \%)$ & $12(20 \%)$ & $0(0 \%)$ \\
Gingiva & $8(62 \%)$ & $19(31 \%)$ & $8(62 \%)$ \\
Floor of the mouth & $0(0 \%)$ & $5(8 \%)$ & $1(8 \%)$ \\
Palate & $0(0 \%)$ & $3(5 \%)$ & $2(15 \%)$ \\
Lip & $0(0 \%)$ & $3(5 \%)$ & $0(0 \%)$ \\
\hline
\end{tabular}

OL showed evidence of infection with any of the HPV subtypes targeted by PCR (Table II).

The clinical diagnosis of OL (homogenous or nonhomogenous) and overexpression of p16 were not significantly correlated $(p=0.74)$; the sensitivity was $19 \%$ and the specificity was $86 \%$ (Table II).

Overexpression of p16 was found in four out of 14 patients with dysplasia compared to nine out of 60 without dysplasia (Table II; $p=0.25$ ). Four patients $(31 \%)$ out of the 13 p16-positive patients displayed dysplasia and 10 patients (16\%) out of 61 patients with p16-negative samples had dysplasia (Table II). A slightly higher incidence of overexpression of p16 was observed among those with OL with dysplasia than OL without dysplasia, although no statistical significance was observed for this difference $(p=0.25)$. This corresponds with a sensitivity of $29 \%$, specificity of $85 \%$, positive predictive value of $31 \%$ and negative predictive value of $84 \%$ for using p16 to identify dysplasia.

In four patients (7\%) with p16-negative samples, lesions progressed from OL to OSCC, while none of the p16positive cases of OL progressed to OSCC (Table II).

Eight patients (62\%) who were adjudged to be p16positive had OL located in the gingiva and 19 samples (31\%) from p16-negative patients had OL in the gingiva $(p=0.057)$. 
Table III. Primers and probes used for the detection of 14 human papillomavirus (HPV) types by real-time polymerase chain reaction.

\begin{tabular}{|c|c|c|}
\hline Target & Oligo & Sequence \\
\hline \multirow[t]{3}{*}{ HPV-6 } & $\mathrm{F}$ & RCGGTTYATAAAGCTAAATTGTACGT \\
\hline & $\mathrm{R}$ & AGGGTAACATGTCTTCCATGCA \\
\hline & $\mathrm{P}$ & AAGGGTCGCTGCCTACACTGCTGG \\
\hline \multirow[t]{3}{*}{ HPV-11 } & $\mathrm{F}$ & GCTTCATAAAACTAAATAACCAGTGGAA \\
\hline & $\mathrm{R}$ & GTCAGGAGGCTGCAGGTCTAGTA \\
\hline & $\mathrm{P}$ & CTATATCCTTTAGGGTAACAAGTCTTCCATGCATGTTG \\
\hline \multirow[t]{3}{*}{ HPV-16 } & $\mathrm{F}$ & TTGCAGATCATCAAGAACACGTAGA \\
\hline & $\mathrm{R}$ & CAGTAGAGATCAGTTGTCTCTGGTTGC \\
\hline & $\mathrm{P}$ & AATCATGCATGGAGATACACCTACATTGCATGA \\
\hline \multirow[t]{3}{*}{ HPV-18 } & $\mathrm{F}$ & AGAGGCCAGTGCCATTCGT \\
\hline & $\mathrm{R}$ & GTTTCTCTGCGTCGTTGGAGT \\
\hline & $\mathrm{P}$ & TCCTGTCGTGCTCGGTTGCAGC* \\
\hline \multirow[t]{3}{*}{ HPV-31 } & $\mathrm{F}$ & ATTCCACAACATAGGAGGAAGGTG \\
\hline & $\mathrm{R}$ & CACTTGGGTTTCAGTACGAGGTCT \\
\hline & $\mathrm{P}$ & ACAGGACGTTGCATAGCATGTTGGA \\
\hline \multirow[t]{3}{*}{ HPV-33 } & $\mathrm{F}$ & ATATTTCGGGTCGTTGGGCA \\
\hline & $\mathrm{R}$ & ACGTCACAGTGCAGTTTCTCTACGT \\
\hline & $\mathrm{P}$ & GGACCTCCAACACGCCGCACA* \\
\hline \multirow[t]{3}{*}{ HPV-35 } & $\mathrm{F}$ & TCGGTGTATGTCCTGTTGGAAAC \\
\hline & $\mathrm{R}$ & CATAGTCTTGCAATGTAGTTATTTCTCCA \\
\hline & $\mathrm{P}$ & TGCATGATTACACCTCGGTTTCTCTACGTG \\
\hline \multirow[t]{3}{*}{ HPV-39 } & $\mathrm{F}$ & GCAGGAAGCTATACAGGACAGTGTC \\
\hline & $\mathrm{R}$ & CTTGGGTTTCTCTTCGTGTTAGTCT \\
\hline & $\mathrm{P}$ & CCCGTTTTGTGGTCCAGCACCG* \\
\hline \multirow[t]{3}{*}{ HPV45 } & $\mathrm{F}$ & GGACAGTACCGAGGGCAGTGTAA \\
\hline & $\mathrm{R}$ & TCCCTACGTCTGCGAAGTCTTTC \\
\hline & $\mathrm{P}$ & CATGTTGTGACCAGGCACGGCA \\
\hline \multirow[t]{3}{*}{ HPV-51 } & $\mathrm{F}$ & AAAGCAAAAATTGGTGGACGA \\
\hline & $\mathrm{R}$ & TGCCAGCAATTAGCGCATT \\
\hline & $\mathrm{P}$ & CATGAAATAGCGGGACGTTGGACG \\
\hline \multirow[t]{3}{*}{ HPV-52 } & $\mathrm{F}$ & GACATGTTAATGCAAACAAGCGAT \\
\hline & $\mathrm{R}$ & CATGACGTTACACTTGGGTCACA \\
\hline & $P$ & TGTTCAGAGTGTTGGAGACCCCGACC \\
\hline \multirow[t]{3}{*}{ HPV-56 } & $\mathrm{F}$ & TGCATTGTGACAGAAAAAGACGAT \\
\hline & $\mathrm{R}$ & CTCCAGCACCCCAAACATG \\
\hline & $\mathrm{P}$ & CCCGGTCCAACCATGTGCTATTAGATGA* \\
\hline \multirow[t]{3}{*}{ HPV-58 } & $\mathrm{F}$ & GGCATGTGGATTTAAACAAAAGGT \\
\hline & $\mathrm{R}$ & TCTCATGGCGTTGTTACAGGTTAC \\
\hline & $\mathrm{P}$ & TGGAGACCCCGACGTAGACAAACACAA \\
\hline \multirow[t]{3}{*}{ HPV-59 } & F & TGTATGGAGAAACATTAGAGGCTGAA \\
\hline & $\mathrm{R}$ & TGGACATAGAGGTTTTAGGCATCTATAA \\
\hline & $P$ & AGACACCGTTACATGAGCTGCTGATACGC \\
\hline \multirow{3}{*}{$\beta$-Globin } & $\mathrm{F}$ & CAGGTACGGCTGTCATCACTTAGA \\
\hline & $\mathrm{R}$ & CATGGTGTCTGTTTGAGGTTGCTA \\
\hline & $\mathrm{P}$ & GCCCTGACTTTTATGCCCAGCCCTG \\
\hline
\end{tabular}

F: Forward-primer; R: reverse-primer; P: probe.

The overexpression of p16 and the gender of the patients did not correlate $(p=0.76)$, nor did smoking $(p=0.52)$ or use of snuff $(p=0.28)$ with the overexpression of $\mathrm{p} 16$.

p16 expression and HPV infection in patients with OSCC. Among the 13 p16-positive patients with OSCC, five (38\%) were positive for HR-HPV (sub-type16) (Table II). Four of these five $(80 \%)$ HPV-positive patients had OSCC in the gingiva and one (20\%) had OSCC in the floor of the mouth. In the eight HPV-negative patients, the tumour was located in the gingiva in six (75\%), and the tongue in two patients $(25 \%)$.

$H P V$ infection in patients with cervical carcinoma. In the control group, four out of five patients (80\%) with p16positive cervical carcinomas were positive for HR-HPV (sub-type 16, 31, 16+31, 51) in the PCR analysis. 


\section{Discussion}

One of the main findings of the present study is that none of the 74 analysed cases of OL were infected with any of the 12 HR-HPV sub-types or either of the two LR-HPV subtypes that were addressed.

This finding was surprising because several previous studies have reported the presence of HPV in OSCC, OL and other potentially malignant oral disorders $(29,30,43)$, and Syrjanän et al., concluded that HPV likely is causally associated with potentially malignant oral disorders and OSCC (24).

Pierangeli et al. reported that $53.2 \%$ of patients with potentially malignant oral disorders were HPV-infected, with HPV types 16 and 18 being the most frequently detected types (43). Isayeva et al. reported the weighted prevalence of HPV DNA was $41.4 \%$ in the 144 cases of potentially malignant oral disorder from 10 different studies, which was significantly higher than in controls (44).

Explanations for the discrepancy between our findings and these of previous studies could be differences in the quality of the samples, in the methodology used, or the geographical region $(44,45)$. Kreimer et al. analyzed the global distribution of HPV genotypes in head and neck squamous cell carcinomas, both in cases of OPSCC and OSCC, and found a higher HPV prevalence of OSCC in Asia than in Europe and the USA $(44,45)$. Nonetheless, we expected to find some HPV-positive cases of OL in our cohort, given that HPV prevalence in the healthy oral mucosa is reported to be $4.5 \%$, including a $3.5 \%$ prevalence of HPV-16 (46).

Another possible explanation for the finding of no HPV infection in our patients with OL is that the mean age of our cohort was rather high at 61 years, with an age range of 2882 years, which is higher than in studies that found a higher prevalence of HPV infection $(47,48)$.

Of the 74 patients with OL, $18 \%$ showed overexpression of p16 but HPV DNA was not detected in any of them. In contrast, HPV-16 was detected in $38 \%$ of the patients in the OSCC group with overexpression of $\mathrm{p} 16$, and $80 \%$ of the patients with cervical carcinoma showed HPV-16 infection. These findings suggest that in patients with OL, overexpression of p16 does not correlate with HPV infection in the same manner as in OSCC and cervical carcinoma.

Angiero et al. have shown that the expression of p16 increases with the presence of dysplasia (49). In line with this, we found that p16 was more often overexpressed in OL with dysplasia. The sensitivity was $29 \%$ and the specificity $84 \%$, which differs from the $83 \%$ sensitivity and $40 \%$ specificity reported by Pathak et al. (50).

The relatively low sensitivity of p16 in identifying dysplasia, and the finding that none of the four patients with OL who developed OSCC were p16-positive indicates that analysis of p16 is not useful for predicting malignant progression of OL. This seems to fit with our finding that
HPV infection, at least of the types targeted by our assay, is not important for the pathogenesis of OL. Furthermore, overexpression of p16 was found not to be a reliable biomarker for HPV infection in patients with OL and OSCC.

\section{Acknowledgements}

This study was supported by grants from The Healthcare Board, Region Västra Götaland (Hälso-och sjukvårdsstyrelsen), TUA Research Funding; The Sahlgrenska Academy at University of Gothenburg/Region Västra Götaland, Assar Gabrielsson Foundation, Adlerbertska Foundation, Swedish Dental Society and Gothenburg Dental Society, Sweden. The Authors acknowledge the valuable assistance of Dr Vincent Collins for English proofreading of the manuscript.

\section{Conflicts of Interest}

The Authors declared no conflicts of interests in regard to this study.

\section{Authors' Contributions}

Jonas Sundberg: participated in the design, planning, analysed and interpreted data and drafted the manuscript; Magdalena Korytowska: analysed and interpreted data, critically reviewed the manuscript; Patricia Miranda Burgos: clinical data collection and follow-up of study patients, critically reviewed the manuscript; Johan Blomgren: clinical data collection and follow-up of study patients, critically reviewed the manuscript; Lena Blomstrand: clinical data collection and follow-up of study patients, critically reviewed the manuscript; Shahin De Lara: performed immunohistochemical staining, co-drafted the immunohistochemistry method part in the manuscript, critically reviewed the manuscript; Lars Sand: participated in the design and study planning, clinical data collection, critically reviewed the manuscript; Jan-Micháel Hirsch: participated in the design and study planning, clinical data collection, critically reviewed the manuscript; Erik Holmberg: statistical analyses, critically reviewed the manuscript; Daniel Giglio: analysed and interpreted data and codrafted the manuscript; Jenny Öhman: participated in the study design, planning, analyses, data interpretation and co-drafted the manuscript; Anikó Kóvacs: histopathological diagnoses, planning, data interpretation and co-drafted the manuscript; Peter Horal: participated in the study design, planning and interpretation of PCR analyses, critically reviewed the manuscript; Magnus Lindh: participated in the study design, planning and interpretation of PCR analyses, co-drafted the manuscript; Göran Kjeller: participated in the design and study planning, clinical data collection, critically reviewed the manuscript; Bengt Hasséus: participated in the design and study planning, clinical data collection, analyses, co-drafted the manuscript.

\section{References}

1 Hanahan D and Weinberg RA: Hallmarks of cancer: The next generation. Cell 144(5): 646-674, 2011. PMID:21376230, DOI:10.1016/j.cell.2011.02.013

2 Haya-Fernandez MC, Bagan JV, Murillo-Cortes J, Poveda-Roda R and Calabuig C: The prevalence of oral leukoplakia in 138 patients with oral squamous cell carcinoma. Oral Dis 10(6): 346-348, 2004. PMID:15533209, DOI:10.1111/j.1601-0825.2004.01031.x 
3 Hunter KD, Parkinson EK and Harrison PR: Profiling early head and neck cancer. Nat Rev Cancer 5(2): 127-135, 2005. PMID: 15685196, DOI:10.1038/nrc1549

4 Warnakulasuriya $\mathrm{S}$ and Ariyawardana A: Malignant transformation of oral leukoplakia: A systematic review of observational studies. J Oral Pathol Med 45(3): 155-166, 2016. PMID:26189354, DOI:10.1111/jop.12339

5 Scheifele $\mathrm{C}$ and Reichart PA: Is there a natural limit of the transformation rate of oral leukoplakia? Oral Oncol 39(5): 470475, 2003. PMID:12747971,

6 Brouns E, Baart J, Karagozoglu K, Aartman I, Bloemena E and van der Waal I: Malignant transformation of oral leukoplakia in a well-defined cohort of 144 patients. Oral Dis 20(3): e19-24, 2014, PMID:23521625, DOI:10.1111/odi.12095

7 Nankivell $\mathrm{P}$ and Mehanna H: Oral dysplasia: Biomarkers, treatment, and follow-up. Curr Oncol Rep 13(2): 145-152, 2011. PMID:21249481, DOI:10.1007/s11912-010-0150-z

8 Mehanna HM, Rattay T, Smith J and McConkey CC: Treatment and follow-up of oral dysplasia - a systematic review and metaanalysis. Head Neck 31(12): 1600-1609, 2009. PMID:19455705, DOI: $10.1002 /$ hed.21131

9 Brennan M, Migliorati CA, Lockhart PB, Wray D, Al-Hashimi I, Axell T, Bruce AJ, Carpenter W, Eisenberg E, Epstein JB, Holmstrup P, Jontell M, Nair R, Sasser H, Schifter M, Silverman B, Thongprasom K, Thornhill M, Warnakulasuriya S and van der Waal I: Management of oral epithelial dysplasia: A review. Oral Surg Oral Med Oral Pathol Oral Radiol Endod 103 Suppl(S19): e11-12, 2007. PMID:17257863, DOI:10.1016/j.tripleo. 2006.10.015

10 Lodi G, Franchini R, Warnakulasuriya S, Varoni EM, Sardella A, Kerr AR, Carrassi A, MacDonald LC and Worthington HV: Interventions for treating oral leukoplakia to prevent oral cancer. Cochrane Database Syst Rev 7(7): CD001829, 2016. PMID:27471845, DOI:10.1002/14651858.CD001829.pub4

11 Pitiyage G, Tilakaratne WM, Tavassoli M and Warnakulasuriya S: Molecular markers in oral epithelial dysplasia: Review. J Oral Pathol Med 38(10): 737-752, 2009. PMID:19903246, DOI:10.1111/j.1600-0714.2009.00804.x

12 Smith J, Rattay T, McConkey C, Helliwell T and Mehanna H: Biomarkers in dysplasia of the oral cavity: A systematic review. Oral Oncol 45(8): 647-653, 2009. PMID:19442563, DOI:10.1016/ j.oraloncology.2009.02.006

13 Dionne KR, Warnakulasuriya S, Zain RB and Cheong SC: Potentially malignant disorders of the oral cavity: Current practice and future directions in the clinic and laboratory. Int $\mathrm{J}$ Cancer 136(3): 503-515, 2015. PMID:24482244, DOI:10.1002/ijc.28754

14 Humans IWGotEoCRt, Meeting IWGotEoCRtH, Organization WH and Cancer IAfRo: Human papillomaviruses. World Health Organization, 2007.

15 Syrjanen S: Oral manifestations of human papillomavirus infections. Eur J Oral Sci 126(Suppl 1): 49-66, 2018. PMID: 30178562, DOI:10.1111/eos.12538

16 Rautava $\mathbf{J}$ and Syrjanen S: Biology of human papillomavirus infections in head and neck carcinogenesis. Head Neck Pathol 6(Suppl 1): S3-15, 2012. PMID:22782219, DOI:10.1007/s12105012-0367-2

17 Gillison ML, Koch WM, Capone RB, Spafford M, Westra WH, Wu L, Zahurak ML, Daniel RW, Viglione M, Symer DE, Shah KV and Sidransky D: Evidence for a causal association between human papillomavirus and a subset of head and neck cancers.
Jnci-Journal of the National Cancer Institute 92(9): 709-720, 2000. PMID: WOS:000086818100013, DOI:DOI 10.1093/jnci/ 92.9.709

18 Mellin H, Friesland S, Lewensohn R, Dalianis T and MunckWikland E: Human papillomavirus (HPV) DNA in tonsillar cancer: Clinical correlates, risk of relapse, and survival. Int J Cancer 89(3): 300-304, 2000. PMID:10861508,

19 Zur Hausen H: Human papillomaviruses and their possible role in squamous cell carcinomas. In: Current topics in microbiology and immunology. Springer, pp. 1-30, 1977.

20 Hennessey PT, Westra WH and Califano JA: Human papillomavirus and head and neck squamous cell carcinoma: Recent evidence and clinical implications. J Dent Res 88(4): 300306, 2009. PMID:19407148, DOI:10.1177/0022034509333371

21 Chaturvedi AK, Engels EA, Anderson WF and Gillison ML: Incidence trends for human papillomavirus-related and -unrelated oral squamous cell carcinomas in the United States. J Clin Oncol 26(4): 612-619, 2008. PMID:18235120, DOI:10.1200/ JCO.2007. 14.1713

22 Nasman A, Attner P, Hammarstedt L, Du J, Eriksson M, Giraud G, Ahrlund-Richter S, Marklund L, Romanitan M, Lindquist D, Ramqvist T, Lindholm J, Sparen P, Ye W, Dahlstrand H, MunckWikland $\mathrm{E}$ and Dalianis T: Incidence of human papillomavirus (HPV) positive tonsillar carcinoma in Stockholm, Sweden: An epidemic of viral-induced carcinoma? Int J Cancer 125(2): 362366, 2009. PMID:19330833, DOI:10.1002/ijc.24339

23 Bisht M and Bist SS: Human papilloma virus: A new risk factor in a subset of head and neck cancers. J Cancer Res Ther 7(3): 251255, 2011. PMID:22044803, DOI:10.4103/0973-1482.87004

24 Syrjanen S, Lodi G, von Bultzingslowen I, Aliko A, Arduino P, Campisi G, Challacombe S, Ficarra G, Flaitz C, Zhou HM, Maeda $\mathrm{H}$, Miller $\mathrm{C}$ and Jontell M: Human papillomaviruses in oral carcinoma and oral potentially malignant disorders: A systematic review. Oral Dis 17(Suppl 1): 58-72, 2011. PMID:21382139, DOI:10.1111/j.1601-0825.2011.01792.x

25 Syrjanen SM, Syrjanen KJ and Happonen RP: Human papillomavirus (hpv) DNA sequences in oral precancerous lesions and squamous cell carcinoma demonstrated by in situ hybridization. J Oral Pathol 17(6): 273-278, 1988. PMID:2849647,

26 Jalouli J, Ibrahim SO, Sapkota D, Jalouli MM, Vasstrand EN, Hirsch JM and Larsson PA: Presence of human papilloma virus, herpes simplex virus and epstein-barr virus DNA in oral biopsies from sudanese patients with regard to toombak use. J Oral Pathol Med 39(8): 599-604, 2010. PMID:20618612, DOI:10.1111/j.16000714.2010.00910.x

27 Mehta V, Yu GP and Schantz SP: Population-based analysis of oral and oropharyngeal carcinoma: Changing trends of histopathologic differentiation, survival and patient demographics. Laryngoscope 120(11): 2203-2212, 2010. PMID:20938956, DOI:10.1002/ lary. 21129

28 Szarka K, Tar I, Feher E, Gall T, Kis A, Toth ED, Boda R, Marton I and Gergely L: Progressive increase of human papillomavirus carriage rates in potentially malignant and malignant oral disorders with increasing malignant potential. Oral Microbiol Immunol 24(4): 314-318, 2009. PMID:19572894, DOI:10.1111/j.1399302X.2009.00516.x

29 Zendeli-Bedjeti L, Popovska M, Atanasovska-Stojanovska A and Duvlis S: Human papillomavirus as a potential risk factor for oral premalignant lesions. Acta Clinica Croatica 56(3): 369-374, 2017. PMID: 29479901, DOI:10.20471/acc.2017.56.03.02 
30 Chen $\mathrm{X}$ and Zhao Y: Human papillomavirus infection in oral potentially malignant disorders and cancer. Arch Oral Biol 83: 334339, 2017. PMID:28886585, DOI:10.1016/j.archoralbio. 2017. 08.011

31 Sikka S and Sikka P: Association of human papilloma virus 16 infection and p53 polymorphism among tobacco using oral leukoplakia patients: A clinicopathologic and genotypic study. Int J Prev Med 5(4): 430, 2014. PMID: 24829730

32 Feller L and Lemmer J: Oral leukoplakia as it relates to HPV infection: A review. Int J Dent 2012: 540561, 2012. PMID: 22505902, DOI: $10.1155 / 2012 / 540561$

33 Witkiewicz AK, Knudsen KE, Dicker AP and Knudsen ES: The meaning of p16ink4a expression in tumors: Functional significance, clinical associations and future developments. Cell Cycle 10(15): 2497-2503, 2011. PMID:21775818, DOI:10.4161/ cc.10.15.16776

34 Serrano M, Hannon GJ and Beach D: A new regulatory motif in cell-cycle control causing specific inhibition of cyclin D/CDK4. Nature 366(6456): 704-707, 1993. PMID:8259215, DOI:10.1038/ $366704 \mathrm{a} 0$

35 Mittal S and Banks L: Molecular mechanisms underlying human papillomavirus E6 and E7 oncoprotein-induced cell transformation. Mutat Res Rev Mutat Res 772: 23-35, 2017. PMID:28528687, DOI:10.1016/j.mrrev.2016.08.001

36 Oguejiofor KK, Hall JS, Mani N, Douglas C, Slevin NJ, Homer $\mathrm{J}$, Hall $\mathrm{G}$ and West CM: The prognostic significance of the biomarker p16 in oropharyngeal squamous cell carcinoma. Clin Oncol (R Coll Radiol) 25(11): 630-638, 2013. PMID:23916365, DOI:10.1016/j.clon.2013.07.003

37 Smeets SJ, Hesselink AT, Speel EJ, Haesevoets A, Snijders PJ, Pawlita M, Meijer CJ, Braakhuis BJ, Leemans CR and Brakenhoff RH: A novel algorithm for reliable detection of human papillomavirus in paraffin embedded head and neck cancer specimen. Int J Cancer 121(11): 2465-2472, 2007. PMID: 17680565, DOI:10.1002/ijc. 22980

38 Lingen MW, Xiao W, Schmitt A, Jiang B, Pickard R, Kreinbrink P, Perez-Ordonez B, Jordan RC and Gillison ML: Low etiologic fraction for high-risk human papillomavirus in oral cavity squamous cell carcinomas. Oral Oncol 49(1): 1-8, 2013. PMID:22841678, DOI:10.1016/j.oraloncology.2012.07.002

39 Belobrov S, Cornall AM, Young RJ, Koo K, Angel C, Wiesenfeld D, Rischin D, Garland SM and McCullough M: The role of human papillomavirus in p16-positive oral cancers. J Oral Pathol Med 47(1): 18-24, 2018. PMID:29024035, DOI:10.1111/jop.12649

40 Salazar CR, Anayannis N, Smith RV, Wang Y, Haigentz M, Jr., Garg M, Schiff BA, Kawachi N, Elman J, Belbin TJ, Prystowsky MB, Burk RD and Schlecht NF: Combined p16 and human papillomavirus testing predicts head and neck cancer survival. Int J Cancer 135(10): 2404-2412, 2014. PMID:24706381, DOI: $10.1002 / \mathrm{ijc} .28876$
41 Sgaramella N, Coates PJ, Strindlund K, Loljung L, Colella G, Laurell G, Rossiello R, Muzio LL, Loizou C, Tartaro G, Olofsson K, Danielsson K, Fahraeus R and Nylander K: Expression of p16 in squamous cell carcinoma of the mobile tongue is independent of hpv infection despite presence of the HPV-receptor syndecan-1. Br J Cancer 113(2): 321-326, 2015. PMID:WOS:000357947800017, DOI:10.1038/bjc.2015.207

42 Lindh M, Gorander S, Andersson E, Horal P, Mattsby-Balzer I and Ryd W: Real-time taqman pcr targeting 14 human papilloma virus types. J Clin Virol 40(4): 321-324, 2007. PMID:17981499, DOI:10.1016/j.jcv.2007.09.009

43 Pierangeli A, Cannella F, Scagnolari C, Gentile M, Sciandra I, Antonelli G, Ciolfi C, Russo C, Palaia G, Romeo U and Polimeni A: Frequent detection of high human papillomavirus DNA loads in oral potentially malignant disorders. Clin Microbiol Infect 22(1): 95 e99-95 e15, 2016. PMID:26408278, DOI:10.1016/j.cmi.2015.09.011

44 Isayeva T, Li Y, Maswahu D and Brandwein-Gensler M: Human papillomavirus in non-oropharyngeal head and neck cancers: A systematic literature review. Head Neck Pathol 6 Suppl 1(1): S104120, 2012. PMID:22782230, DOI:10.1007/s12105-012-0368-1

45 Kreimer AR, Clifford GM, Boyle P and Franceschi S: Human papillomavirus types in head and neck squamous cell carcinomas worldwide: A systematic review. Cancer Epidemiol Biomarkers Prev 14(2): 467-475, 2005. PMID:15734974, DOI:10.1158/10559965.EPI-04-0551

46 Kreimer AR, Bhatia RK, Messeguer AL, Gonzalez P, Herrero R and Giuliano AR: Oral human papillomavirus in healthy individuals: A systematic review of the literature. Sex Transm Dis 37(6): 386-391, 2010. PMID:20081557, DOI:10.1097/OLQ.0b013e3181c94a3b

47 Robinson KL and Macfarlane GJ: Oropharyngeal cancer incidence and mortality in scotland: Are rates still increasing? Oral Oncol 39(1): 31-36, 2003. PMID:12457719,

48 Conway DI, Stockton DL, Warnakulasuriya KA, Ogden G and Macpherson LM: Incidence of oral and oropharyngeal cancer in united kingdom (1990-1999) - recent trends and regional variation. Oral Oncol 42(6): 586-592, 2006. PMID:16469526, DOI:10.1016/j.oraloncology.2005.10.018

49 Angiero F, Berenzi A, Benetti A, Rossi E, Del Sordo R, Sidoni A, Stefani $M$ and Dessy E: Expression of p16, p53 and ki-67 proteins in the progression of epithelial dysplasia of the oral cavity. Anticancer Res 28(5A): 2535-2539, 2008. PMID:19035275,

50 Pathak A, Singh M, Agarwal A and Amit S: Determination of p16 overexpression as an indicator of human papillomavirus infection in oral dysplasia and carcinoma. Indian J Dent Res 28(4): 418, 2017. PMID:28836534, DOI:10.4103/ijdr.IJDR_79_15

Received December 31, 2018

Revised January 25, 2019

Accepted February 6, 2019 